\title{
1 The proficiency of the original host species determines community-level plasmid dynamics
}

\section{Anastasia Kottara ${ }^{1 *}$, James P.J. Hall ${ }^{2}$, Michael A. Brockhurst ${ }^{11^{*}}$}

$3 \quad{ }^{1}$ Department of Animal and Plant Sciences, University of Sheffield, Sheffield, S10 2TN, UK

$4 \quad{ }^{2}$ Department of Evolution, Ecology and Behaviour, Institute of Integrative Biology, University of

$5 \quad$ Liverpool, Liverpool, L69 7ZB, UK

6 Current address: Instituto Gulbenkian de Ciência, Rua Quinta Grande 6, Oeiras 2780-156, Portugal

$7 \quad{ }^{\$}$ Current address: Division of Evolution and Genomic Sciences, Faculty of Biology, Medicine and

8 Health, University of Manchester, Manchester, M13 9PT, UK.

9

10 Corresponding author: Michael Brockhurst, Division of Evolution and Genomic Sciences, Faculty of

11 Biology, Medicine and Health, University of Manchester, Manchester, M13 9PT, UK. Email-

12 michael.brockhurst@manchester.ac.uk

13

14 Keywords: horizontal gene transfer, mobile genetic elements, conjugative plasmids, bacterial

15 communities, plasmid transfer. 


\section{ABSTRACT}

27 Plasmids are common in natural bacterial communities, facilitating bacterial evolution via horizontal

28 gene transfer. Bacterial species vary in their proficiency to host plasmids: Whereas plasmids are stably

29 maintained in some species regardless of selection for plasmid-encoded genes, in other species, even

30 beneficial plasmids are rapidly lost. It is, however, unclear how this variation in host proficiency affects

31 plasmid persistence in communities. Here, we test this using multispecies bacterial soil communities comprising species varying in their proficiency to host a large conjugative mercury resistance plasmid.

33 Plasmids reached higher community-level abundance where beneficial and when introduced to the

34 community in a more proficient host species. Proficient plasmid host species were also better able to

35 disseminate the plasmid to a wider diversity of host species. These findings suggest that the dynamics

36 of plasmids in natural bacterial communities depend not only upon the plasmid's attributes and the

37 selective environment, but also upon the proficiency of their host species. 


\section{INTRODUCTION}

53 Mobile genetic elements (MGEs) like plasmids, temperate bacteriophages, and transposons, are

54 important agents of horizontal gene transfer (HGT) driving the diversification of bacterial genomes

55 (Frost et al. 2005; Hall, Brockhurst and Harrison 2017a; Brockhurst et al. 2019). Conjugative plasmids

56 contain genes encoding core plasmid functions - including their own propagation, replication, stability

57 and transfer - along with accessory genes that encode traits like antibiotic and metal resistance

58 (Norman, Hansen and Sørensen 2009). While the plasmid's accessory genes can directly benefit the

59 host cell by providing them with new ecological functions, the plasmid's core functions can impose a

60 heavy burden on the host cell, the accessory genes can directly benefit the host cell by providing them with new ecological functions (Baltrus 2013; San Millan and Maclean 2017). Mathematical models of plasmid population dynamics suggest that the plasmid cost, conjugation rate, segregation rate, and the strength of positive selection are key parameters determining plasmid survival in bacterial populations (Stewart and Levin 1977; Levin, Stewart and Rice 1979; Simonsen et al. 1990; Bergstrom, Lipsitch and Levin 2000).

Plasmids are expected to spread under positive selection for their encoded accessory genes (San

Millan et al. 2014; Harrison et al. 2015), however, because accessory genes can be captured by the bacterial chromosome rendering the plasmid redundant, positive selection does not guarantee the longterm survival of plasmids (Bergstrom, Lipsitch and Levin 2000). Meanwhile, in the absence of positive selection, plasmids are expected to go extinct due to purifying selection because the benefits of accessory genes do not outweigh the costs of plasmid carriage (Bergstrom, Lipsitch and Levin 2000). Since rates of conjugation appear to often be too low for plasmids to persist as infectious elements (although see: Lopatkin et al. (2017) and Stevenson et al. (2017)), it has been argued that the widespread distribution of plasmids is paradoxical (the plasmid paradox: Harrison and Brockhurst (2012)). Yet, plasmids have been found to stably persist in natural bacterial communities in the absence of measurable positive selection, where the factors allowing plasmid stability are puzzling (Heuer and Smalla 2012). 
which plasmids can survive. This limitation of current understanding is particularly interesting considering that several studies have shown that plasmids are not equally stable across host species (De

81 Gelder et al. 2007; Kottara et al. 2018; Sakuda et al. 2018). For example, while the mercury resistance plasmid pQBR103 was highly stable for $>400$ generations with or without mercury selection in $P$. fluorescens and P. savastanoi, it was unstable to varying degrees in P. stutzeri (generally lost within $\sim 100-400$ generations), P. aeruginosa and P. putida ( $<6$ generations) even with strong mercury selection (Kottara et al. 2018).

Hall et al. (2016) showed, by tracking the dynamics of the mercury resistance plasmid pQBR57 in a two-species soil community of $P$. fluorescens and $P$. putida, that between-species transfer of the plasmid from a proficient host, $P$. fluorescens, to an unstable host, $P$. putida, allowed the plasmid to persist in P. putida both with and without mercury selection. This finding suggests that the dynamics of a plasmid in a bacterial community is likely to depend on the proficiency of the plasmid host species to stably maintain the plasmid. This leads to the prediction that, at the community-level, plasmid abundance will be higher in communities where it is carried by a proficient original plasmid host, since this species will both be able to maintain the plasmid in its own population, and then disseminate the plasmid to other species in the community.

To test this prediction, we tracked the dynamics of pQBR103 in a three-species community of P. fluorescens, $P$. stutzeri and P. putida with and without mercury selection. We varied which of the species carried the plasmid at the start of the experiment. We hypothesised that the community-level plasmid abundance would vary according to the proficiency of the original plasmid host species to act as hosts to $\mathrm{pQBR} 103$, which varies hierarchically $-P$. fluorescens $>$ P. stutzeri $>$ P. putida (Kottara et al. 2018). Replicate communities were propagated in effectively sterile potting soil microcosms, which provide spatial structure and a low resource environment that more closely resemble the natural physical and chemical conditions in soil and promote the stable co-existence of multiple bacterial species 


\section{Bacterial strains and plasmid}

Three Pseudomonas species - P. fluorescens SBW25 (Rainey, Bailey and Thompson 1994), P. stutzeri

JM300 (DSM 10701) (Busquets et al. 2012) and P. putida KT2440 (Bagdasarian et al. 1981) - were

utilised in this study. Pseudomonas species were labelled by directed insertion of either streptomycin

$110\left(\mathrm{Sm}^{\mathrm{R}}\right)$ or gentamicin resistance $\left(\mathrm{Gm}^{\mathrm{R}}\right)$ marker using the mini- $\mathrm{Tn} 7$ transposon system (Lambertsen,

111 Sternberg and Molin 2004). The plasmid used in this study, pQBR103 is a large conjugative plasmid

$112(425 \mathrm{~kb})$ that confers mercury resistance via a mer operon encoded on a Tn5042 transposon (Lilley et

113 al. 1996; Tett et al. 2007). pQBR103 plasmid is part of a group of 136 plasmids that were isolated from

114 the bacterial community inhabiting the sugar beet rhizosphere and phyllosphere during a long-term field experiment (Lilley et al. 1996). pQBR103 was acquired by conjugation into labelled strain of $P$.

fluorescens that was introduced onto the naturally occurring bacterial community colonising the sugar

beet rhizosphere with the primary plasmid-host remaining unknown (Lilley et al. 1996). To obtain the initial plasmid-bearing clones of each host species to start the selection experiment, pQBR103 plasmid was conjugated into P. stutzeri $\mathrm{Gm}^{\mathrm{R}}, P$. putida $\mathrm{Sm}^{\mathrm{R}}$ and P. fluorescens $\mathrm{Sm}^{\mathrm{R}}$ lacZ from the plasmidat $28^{\circ} \mathrm{C}$ in shaking conditions (180 rpm).

\section{Selection experiment}

128 To account for the high segregation rate of the plasmid in P. putida KT2440 (Kottara et al. 2018) and to ensure high starting frequencies of plasmid carriage across all the tested bacterial strains, single colonies of each plasmid-bearing species were reconditioned overnight and then transferred in fresh media containing mercury. Specifically, individual colonies $(n=12)$ of each plasmid-bearing

132 Pseudomonas species were picked into separate $6 \mathrm{~mL} \mathrm{~KB}$ microcosms and incubated overnight at $28^{\circ} \mathrm{C}$ 
133 with shaking $180 \mathrm{rpm}$ after which time $1 \%$ of each population was transferred to grow for $24 \mathrm{~h}$ in fresh

$134 \mathrm{~KB}$ microcosms containing $50 \mu \mathrm{M}$ of mercury(II) chloride at same temperature and shaking conditions;

135 this concentration of mercury was used to select for the pQBR103 plasmid based on previous findings

136 (Kottara et al. 2018). Similarly, 24 colonies of each plasmid-free Pseudomonas species were each

137 grown overnight in $\mathrm{KB} 6 \mathrm{~mL}$ microcosms and transferred to grow for $24 \mathrm{~h}$ in fresh $\mathrm{KB}$ microcosms at

138 same temperature and shaking conditions.

Bacterial communities

141 We used soil microcosms to evolve three different bacterial communities differing by which species

142 carried the plasmid at the beginning of the experiment (original plasmid host). To prepare the soil

143 microcosms, we added $10 \mathrm{~g}$ of John Innes No. 2 compost soil in $30 \mathrm{~mL}$ universal vials which we

144 autoclaved twice. By autoclaving the compost soil two times, we established an effectively sterile

145 micro-environment with the physical and chemical properties of soil which did not contain other

146 culturable bacteria than our inoculum (Gómez and Buckling 2010; Hall et al. 2015; Hall et al. 2016).

147 Three different bacterial communities were then constructed: P. fluorescens (carrying pQBR103) with

148 P. stutzeri and P. putida; P. fluorescens with P. stutzeri (pQBR103) and P. putida; P. fluorescens with

149 P. stutzeri and P. putida (pQBR103). Six replicates of each community were grown either without mercury or with mercury $\left(16 \mu \mathrm{g} \mathrm{g}^{-1} \mathrm{Hg}(\mathrm{II})\right)$; this concentration of mercury was used to select for the pQBR103 plasmid while could allow the survival of the plasmid-free species based on previous findings

(Hall et al. 2015). Each community had a starting ratio of 1:1:1 of each Pseudomonas species such that the starting frequency of pQBR103 in the community was approximately $33 \%$. To remove spent media and residual mercury from overnight cultures each inoculum was briefly vortexed, then centrifuged for $1 \mathrm{~min}$ at 10,000 rpm and resuspended in $1 \mathrm{~mL}$ M9 salt solution (Cold Spring Harbor Protocols). $100 \mu \mathrm{L}$ was then inoculated into soil microcosms and incubated at $28^{\circ} \mathrm{C}$ at $80 \%$ humidity (Hall et al. 2016).

159 Every 4 days, $10 \mathrm{~mL}$ of M9 buffer and 20 glass beads were added to each soil microcosm and mixed 160 by vortexing for $1 \mathrm{~min}$, and $100 \mu \mathrm{L}$ of soil wash was transferred to a fresh soil microcosm as previously 
described by Hall et al. (2016). Bacterial counts for each species were estimated by plating onto selective media: $50 \mu \mathrm{g} \mathrm{mL}^{-1}$ streptomycin $+50 \mu \mathrm{g} \mathrm{mL}^{-1} \mathrm{X}-\mathrm{Gal} \mathrm{KB}$ agar plates and $5 \mu \mathrm{g} \mathrm{mL}{ }^{-1}$ gentamicin $\mathrm{KB}$ agar plates, each of which was then replica plated onto mercury KB agar plates (100 $\mu \mathrm{M}$ mercury(II) chloride). The bacterial communities were evolved for 10 transfers ( $\sim 40$ days).

\section{Plasmid and mercury-transposon screening}

167 Twenty-four mercury-resistant colonies of each Pseudomonas species were sampled every 2 transfers from the mercury containing plates and tested for the presence of the plasmid and mercury transposon by PCR screening. The PCR used the same sets of primers as previously described [mer operon on the Tn5042 transposon - forward primer: TGCAAGACACCCCCTATTGGAC, reverse primer:

TTCGGCGACCAGCTTGATGAAC and origin of replication of the plasmid (oriV) - forward primer: 2015; Kottara et al. 2018).

\section{Statistics}

176 Statistical analyses were performed using RStudio version 3.2.3 (R Core Team 2013). Shapiro-Wilk test, normal Q-Q plots, histograms and box-plots were used to examine the normality of the data. We found that in most cases the data were not normally distributed, and in such cases used a non-parametric test. Cumulative plasmid abundance in each community over time was estimated as the area under the curve using the function auc of the package 'flux' (Jurasinski, Koebsch and Hagemann 2012).

181 Community-level plasmid abundances in the plasmid host treatments were compared by using the

182 Kruskal-Wallis test. To assess the plasmid-dynamics within each species, we compared plasmid 183 frequencies in the plasmid-recipient species population as the area under the curve. The integral estimates of the plasmid frequency in the recipient species were compared between the mercury conditions using the Kruskal-Wallis test. To assess the timing of chromosomal acquisition of the mercury transposon Tn5042 in P. putida differed between the plasmid host treatments, for each 
genotypes of $P$. putida. We compared these values between the plasmid host treatments using the Kruskal-Wallis test. The species diversity of plasmid-carriers was calculated as the 1 - D Simpson's

Index, 1- $\left[\sum=\left(\frac{n}{N}\right)^{2}\right]$ where, $\mathrm{n}=$ the end-point population density of each plasmid-bearer species in community, and, $\mathrm{N}=$ the end-point population density of all plasmid-bearer species. We compared diversities between the plasmid host treatments and mercury conditions by using the Kruskal-Wallis test.

\section{RESULTS}

\section{Original plasmid host species identity affects community-level plasmid abundance}

The bacterial host species vary in their ability to stably maintain pQBR103 hierarchically as follows: mercury resistance at the community-level. To test this, we quantified the total plasmid abundance in each community (Figure 1). Mercury selection increased total plasmid abundance (effect of mercury; $\left.X^{2}(1, \mathrm{~N}=24)=17.28, \mathrm{p}=3.226 \mathrm{e}-05\right)$ and total plasmid abundance varied with original plasmid host identity, such that both with (effect of plasmid treatment; $X^{2}(2, \mathrm{~N}=18)=11.556, \mathrm{p}=0.003$ ) and without (effect of plasmid treatment; $\left.X^{2}(2, \mathrm{~N}=18)=11.474, \mathrm{p}=0.003\right)$ mercury selection, the total plasmid abundance was higher when the original plasmid host was $P$. fluorescens. Together these data suggest that community-level plasmid dynamics are affected by both the positive selection for plasmid-encoded traits and the identity of the original plasmid host species, being enhanced when plasmids are beneficial and carried by a proficient plasmid host.

\section{Species-level plasmid dynamics within communities}

211 To understand how the variation in community-level plasmid abundance was driven by original plasmid

212 host identity, we next examined the species-level plasmid dynamics in each community. As predicted,

213 when a proficient plasmid-host - P. fluorescens - was the original plasmid host it maintained the 214 plasmid at high frequency within its population both with and without mercury (Figure 2). We detected 
plasmid dissemination from $P$. fluorescens to the other species at higher frequencies under mercury selection (effect of mercury; $X^{2}(1, \mathrm{~N}=24)=4.653, \mathrm{p}=0.030$ ). This occurred to $P$. putida in all replicates and to $P$. stutzeri in $2 / 6$ replicates with mercury selection and also to $P$. stutzeri at low levels in some of the communities without mercury selection. When P. stutzeri was the original plasmid host, it also maintained the plasmid within its own population both with and without mercury, and disseminated plasmids to the other species at a higher rate with mercury (effect of mercury; $\mathcal{X}^{2}(1, \mathrm{~N}=24)=11.644$, $\mathrm{p}=0.0006$ ) (Figure 3). Variation in total plasmid abundance between replicate communities in this treatment appear to have been caused by whether or not $P$. fluorescens acquired the plasmid before it was driven extinct by toxic mercury: where transmission to $P$. fluorescens occurred, total plasmid abundances were higher (Figure 3). Where $P$. putida was the original plasmid host, it did not maintain the plasmid within its own population: without mercury, the plasmid was simply lost, whereas, with mercury, plasmid-bearers were replaced by mutants that had inserted the Tn5042 encoding the mer operon into their chromosome (Figure 4). Chromosomal insertions of the Tn5042 in P. putida were observed in the other plasmid host treatments, but arose much later in these communities where $P$. putida had to acquire the plasmid horizontally from either $P$. fluorescens or $P$. stuzeri (effect of treatment; $\left.X^{2}(2, \mathrm{~N}=18)=10.947, \mathrm{p}=0.004\right)$. Although $P$. putida eventually lost the plasmid from its own population, prior to this loss it successfully disseminated the plasmid to $P$. fluorescens in $6 / 6$ replicates and to $P$. stutzeri in 3/6 replicates with mercury selection (Figure 4).

\section{Diversity of plasmid-carriers in communities}

235 Finally, we tested how the original plasmid host identity affected the diversity of plasmid-carriers at the end of the experiment. The diversity of plasmid-carriers was affected by both the original plasmid host species identity (effect of plasmid treatment; $\left.X^{2}(2, \mathrm{~N}=36)=12.819, \mathrm{p}=0.001\right)$ and mercury selection (effect of mercury; $\left.X^{2}(1, \mathrm{~N}=36)=6.082, \mathrm{p}=0.013\right)$ (Figure 5). Without mercury selection the diversity of plasmid-carriers was highest when P. stutzeri was the original plasmid host. Whereas, with mercury

240 selection, the diversity of plasmid-carriers was higher in communities where $P$. fluorescens or $P$. 
242 plasmid host. Consistent with our data on community-level plasmid abundance, these data show that

243 the diversity of plasmid-carriers is likely to be higher when plasmids are beneficial and are introduced

244 to the community by proficient plasmid hosts.

\section{DISCUSSION}

247 In natural microbial communities, broad host range plasmids are frequently transmitted to diverse host

248 species thus highlighting the importance of plasmids in HGT and their role in the spread of resistance

249 genes in the environment (Klümper et al. 2015). In this study, we aimed to understand the extent to

250 which plasmid dynamics in a bacterial community are affected by the original plasmid host species

251 identity within that community. Our findings suggest that plasmid abundance at the community-level

252 was driven by the identity of the original plasmid host species. We observed that pQBR103 reached higher community-level abundance when hosted by a proficient plasmid-host, $P$. fluorescens. Dionisio et al. (2002) have previously shown the importance of species identity in shaping the plasmid dynamics in a community. This was further described by Hall et al. (2016) where a proficient plasmid-host could act as a source of the plasmid for a non-proficient host species in a two-species soil community. These plasmid dynamics were explained in terms of conjugative plasmids persisting in the community as infectious agents via interspecies transfer (Bahl, Hansen and Sørensen 2007). Here, we extend these results to a more complex three-species community, a different plasmid, and a wider range of plasmid host species and proficiencies.

The community-level plasmid abundance also varied according to mercury selection. In common with previous studies (Cairns et al. 2018), plasmids were observed at higher frequencies in recipient species in the presence versus absence of positive selection. Detecting HGT events is more likely under positive selection, because, while individual conjugation events may be rare, positively selected horizontally acquired genes will rise to high frequency due to clonal expansion. This has led to a generally accepted, but probably incorrect view, that HGT is accelerated under positive selection

267 (Aminov 2011; Fletcher 2015). By contrast, recent experimental data shows that horizontal transmission plays a more important role in plasmid stability in the absence of positive selection 
269 (Stevenson et al. 2017), leading to higher rates of gene mobilisation and transfer in these environments

270 (Hall et al. 2017b). Mercury selection also drove the invasion of $P$. putida mutants that had lost the

271 plasmid but captured the Tn5042 carrying the mercury resistance operon to the chromosome, an

272 outcome rarely observed in the other host species. This confirms our previous data that the rate and/or

273 propensity for transposition of traits from the plasmid to the chromosome is variable among

274 Pseudomonas species (Kottara et al. 2018). We show here that the dynamics of this process are affected

275 by the community context, specifically whether or not $P$. putida was the original plasmid host.

276 Chromosomal capture of mercury resistance transposon in P. putida occurred earlier when it began the

277 experiment with the plasmid, reflecting that transposition is random mutational event and thus more

278 likely to occur in larger - plasmid-bearing - populations. Interestingly, however, our data also show

279 that even low proficiency plasmid hosts, which rapidly capture useful traits and jettison the plasmid,

can act as a source of plasmids for other species in community by transferring the plasmid to more

proficient host species before it is lost.

In contrast to the study of Hall et al. (2016), which used a highly conjugative plasmid, pQBR57, the plasmid used here, pQBR103, has $>1000$-fold lower conjugation rate $(\gamma)\left(\log _{10}(\gamma)\right.$ pQBR103 $=\sim-$ 13.8, $\log _{10}(\gamma) \mathrm{pQBR} 57=\sim-10.8$; Hall et al. 2015). While previous studies of pQBR103 have focused on the importance compensatory evolution in its longer-term stability (Harrison et al. 2015), here we show an effect of between species conjugation increasing the community-level abundance of the plasmid. The role for interspecific conjugation in pQBR103 stability was most notable in communities where it was initially carried by a non-proficient original plasmid host, $P$. putida. Here, while the plasmid started in $\sim 33 \%$ of the population and went extinct in the $P$. putida population, it survived in the community by horizontal transmission, most commonly into $P$. fluorescens. Through interspecific conjugation, pQBR103 increased the diversity of plasmid-carriers in communities, especially under mercury selection. However, this effect depended upon the original plasmid host species identity.

293 Conjugation also depends on the population density, and in this case the higher population density of P. fluorescens could have enabled the plasmid transfer from P. fluorescens. Surprisingly, although with mercury selection more proficient plasmid host species (i.e. P. fluorescens and P. stutzeri) allowed 
proficient plasmid host, P. stutzeri, was original plasmid host where the highest plasmid-carrier diversity was observed. This effect is likely to have been caused by the more equitable distribution of plasmid carriage in these communities, and specifically by higher rates of plasmid carriage in $P$. stutzeri itself compared to communities where this species had to obtain the plasmid via conjugation. hot spots for HGT (van Elsas and Bailey 2002; Sørensen et al. 2005) due to the spatially structured nature of such environments (Bahl, Hansen and Sørensen 2007; Fox et al. 2008; Røder et al. 2013). Here, we show that the identity of original plasmid host species determines the community-level abundance of conjugative plasmids in soil bacterial communities. Proficient plasmid hosts better maintain plasmids within their own population and transmit these plasmids to other species in the community. This implies that proficient plasmid host species could promote the robustness of communities by spreading potentially adaptive genes to more diverse species, allowing their survival upon environmental deterioration in the future.

\section{ACKNOWLEDGEMENTS}

314 The authors thank T. Daniell and D. Rozen for their comments on a previous version of this work.

\section{FUNDING}

317 This work was supported by funding from the European Research Council under the European Union's

318 Seventh Framework Programme awarded to MB [grant number FP7/2007-2013/ERC grant StG-2012319 311490-COEVOCON] and a grant to MB from the Natural Environment Research Council $320 \quad \mathrm{NE} / \mathrm{R} 008825 / 1$. 
$323 \mathrm{AK}, \mathrm{JH}$ and $\mathrm{MB}$ designed the study; AK performed the experiments and analysed the data; $\mathrm{AK}$ and $\mathrm{MB}$

324 drafted the manuscript.

325

326 Conflict of interest. The authors declare that there are no conflicts of interest.

327

\section{REFERENCES}

329 Aminov RI. Horizontal gene exchange in environmental microbiota. Front Microbiol 2011;2:158.

330 Bagdasarian M, Lurz R, Rückert B et al. Specific-purpose plasmid cloning vectors II. Broad host range, 331 high copy number, RSF 1010-derived vectors, and a host-vector system for gene cloning in Pseudomonas. Gene 1981;16:237-247.

Bahl MI, Hansen LH, Sørensen SJ. Impact of conjugal transfer on the stability of IncP-1 plasmid pKJK5 in bacterial populations. FEMS Microbiol Lett 2007;266:250-256.

Baltrus DA. Exploring the costs of horizontal gene transfer. Trends Ecol Evol 2013;28:489-495.

336 Bergstrom CT, Lipsitch M, Levin BR. Natural selection, infectious transfer and the existence conditions for bacterial plasmids. Genetics 2000;155:1505-1519.

Brockhurst MA, Harrison E, Hall JP et al. The ecology and evolution of pangenomes. Curr Biol 2019;29:R1094-R1103. DOI: 10.1016/j.cub.2019.08.012

Busquets A, Peña A, Gomila M et al. Genome sequence of Pseudomonas stutzeri strain JM300 (DSM 10701), a soil isolate and model organism for natural transformation. $J$ Bacteriol 2012;194:54775478.

343 Cairns J, Ruokolainen L, Hultman J et al. Ecology determines how low antibiotic concentration impacts community composition and horizontal transfer of resistance genes. Commun Biol 2018;1:1-8.

345 De Gelder L, Ponciano JM, Joyce P et al. Stability of a promiscuous plasmid in different hosts: no guarantee for a long-term relationship. Microbiology 2007;153:452-463.

347 Dionisio F, Matic I, Radman M et al. Plasmids spread very fast in heterogeneous bacterial communities. 
349 Fletcher S. Understanding the contribution of environmental factors in the spread of antimicrobial resistance. Environ Health Prev Med 2015;20:243.

351 Fox RE, Zhong X, Krone SM et al. Spatial structure and nutrients promote invasion of IncP-1 plasmids in bacterial populations. ISME J. 2008;2:1024-1039.

353 Frost LS, Leplae R, Summers AO et al. Mobile genetic elements: the agents of open source evolution. Nature Rev Microbiol. 2005;3:722-732.

Gómez P, Buckling A. Bacteria-phage antagonistic coevolution in soil. Science 2011;332:106-109.

Hall JP, Harrison E, Lilley AK et al. Environmentally co-occurring mercury resistance plasmids are genetically and phenotypically diverse and confer variable context-dependent fitness effects. Environ Microbiol 2015;17:5008-5022.

Hall JP, Wood AJ, Harrison E et al. Source-sink plasmid transfer dynamics maintain gene mobility in soil bacterial communities. P Natl Acad Sci USA 2016;113:8260-8265.

Hall JP, Brockhurst MA, Harrison E. Sampling the mobile gene pool: innovation via horizontal gene transfer in bacteria. Philos Trans R Soc B 2017a;372:20160424. DOI: 10.1098/rstb.2016.0424

Hall JP, Williams D, Paterson S et al. Positive selection inhibits gene mobilization and transfer in soil bacterial communities. Nat Ecol Evol 2017b;1:1348-1353.

Harrison E, Brockhurst MA. Plasmid-mediated horizontal gene transfer is a coevolutionary process. Trends Microbiol 2012;20:262-267.

367 Harrison E, Guymer D, Spiers AJ et al. Parallel compensatory evolution stabilizes plasmids across the parasitism-mutualism continuum. Curr Biol 2015;25:2034-2039.

369 Heuer H, Smalla K. Plasmids foster diversification and adaptation of bacterial populations in soil. FEMS Microbiol Rev 2012;36:1083-1104. measurements. $R$ package 2012; version 0.2-1. 
373 Klümper U, Riber L, Dechesne A et al. Broad host range plasmids can invade an unexpectedly diverse 374 fraction of a soil bacterial community. ISME J 2015;9:934-945.

375 Kottara A, Hall JP, Harrison E et al. Variable plasmid fitness effects and mobile genetic element dynamics across Pseudomonas species. FEMS Microbiol Ecol 2018;94:fix172. DOI: 10.1093/femsec/fix172

Lambertsen L, Sternberg C, Molin S. Mini-Tn7 transposons for site-specific tagging of bacteria with fluorescent proteins. Environ Microbiol 2004;6:726-732.

Levin BR, Stewart FM, Rice VA. The kinetics of conjugative plasmid transmission: fit of a simple mass action model. Plasmid 1979;2:247-260.

Lilley AK, Bailey MJ, Day MJ et al. Diversity of mercury resistance plasmids obtained by exogenous isolation from the bacteria of sugar beet in three successive years. FEMS Microbiol Ecol 1996;20:211-227.

Lopatkin AJ, Meredith HR, Srimani JK et al. Persistence and reversal of plasmid-mediated antibiotic resistance. Nat Commun 2017;8:1-10.

Norman A, Hansen LH, Sørensen SJ. Conjugative plasmids: vessels of the communal gene pool. Phil Trans R Soc B 2009;364:2275-2289.

R Core Team. R: A language and environment for statistical computing. R Foundation for Statistical Computing, Vienna, Austria. 2013;Online: http://www. R-project. org.

Rainey PB, Bailey MJ, Thompson IP. Phenotypic and genotypic diversity of fluorescent pseudomonads isolated from field-grown sugar beet. Microbiology 1994;140:2315-2331.

Røder HL, Hansen LH, Sørensen SJ et al. The impact of the conjugative IncP-1 plasmid pKJK5 on multispecies biofilm formation is dependent on the plasmid host. FEMS Microbiol Lett 2013;344:186-192. coexisting recipient candidates. $m$ Sphere 2018;3:e00490-18. DOI: 10.1128/mSphere.00490-18 
398 San Millan A, Peña-Miller R, Toll-Riera M et al. Positive selection and compensatory adaptation 399 interact to stabilize non-transmissible plasmids. Nat Commun 2014;5:1-11.

400 San Millan A, MacLean RC. Fitness costs of plasmids: a limit to plasmid transmission. Microbiol Spectr 2017;5. DOI: 10.1128/microbiolspec.MTBP-0016-2017

402 Simonsen L, Gordon DM, Stewart FM et al. Estimating the rate of plasmid transfer: an end-point method. Microbiology 1990;136:2319-2325.

404 Sørensen SJ, Bailey M, Hansen LH et al. Studying plasmid horizontal transfer in situ: a critical review. Nat Rev Microbiol 2005;3:700-710.

406 Stevenson C, Hall JP, Harrison E et al. Gene mobility promotes the spread of resistance in bacterial populations. ISME J 2017;11:1930-1932.

408 Stewart FM, Levin BR. The population biology of bacterial plasmids: a priori conditions for the 409 existence of conjugationally transmitted factors. Genetics. 1977;87:209-228.

410 Tett A, Spiers AJ, Crossman LC et al. Sequence-based analysis of pQBR103; a representative of a 411 unique, transfer-proficient mega plasmid resident in the microbial community of sugar beet. ISME J. 2007;1:331-340.

413 Torsvik V, Øvreås L. Microbial diversity and function in soil: from genes to ecosystems. Curr Opin Microbiol 2002;5:240-245

415 van Elsas JD, Bailey MJ. The ecology of transfer of mobile genetic elements. FEMS Microbiol Ecol 416 2002;42:187-197. 
Figure Legends

2 Figure 1. Total plasmid density in the community throughout the selection experiment. Panels data for communities that varied in mercury selection (without mercury, left-hand set; with mercury, right-hand set) their initial original plasmid host (from left to right in each set: P. fluorescens, P. stutzeri or $P$. putida). Brown shaded area shows the mean plasmid abundance in the community \pm standard error (dotted line) from six replicates. Solid lines show the mean total community bacterial density from six replicates.

9 Figure 2. Population density and mobile genetic element dynamics in communities where $\boldsymbol{P}$.

10 fluorescens was the original plasmid host. A-F clonal populations evolving with or without mercury.

11 Lines show the population densities of P. fluorescens (blue); P. stutzeri (red); P. putida (green). Brown

12 areas show the density of plasmid carriers; Grey areas show the density of cells that have retained the

13 Tn5042 but lost the plasmid.

15 Figure 3. Population density and mobile genetic element dynamics in communities where $\boldsymbol{P}$. stutzeri was the original plasmid host. A-F clonal populations evolving with or without mercury. Lines show the population densities of $P$. fluorescens (blue); P. stutzeri (red); P. putida (green). Brown areas show the density of plasmid carriers; Grey areas show the density of cells that have retained the Tn5042 but lost the plasmid.

Figure 4. Population density and mobile genetic element dynamics in communities where $\boldsymbol{P}$. putida was the original plasmid host. A-F clonal populations evolving with or without mercury. Lines show the population densities of $P$. fluorescens (blue); P. stutzeri (red); P. putida (green). Brown areas show the density of plasmid carriers; Grey areas show the density of cells that have retained the Tn5042 but lost the plasmid.

27 Figure 5. Diversity of plasmid-carriers at the end of the experiment. Species diversity was calculated as the 1-D Simpson's Index by using the end-point population densities of the plasmid-carriers in each species in each original plasmid host community. 
bioRxiv preprint doi: https://doi.org/10.1101/2020.10.13.337451; this version posted October 13, 2020. The copyright holder for this preprint (which was not certified by peer review) is the author/funder, who has granted bioRxiv a license to display the preprint in perpetuity. It is made available under aCC-BY-NC-ND 4.0 International license.

$0 \mu \mathrm{g} / \mathrm{g} \mathrm{Hg}$ (II)

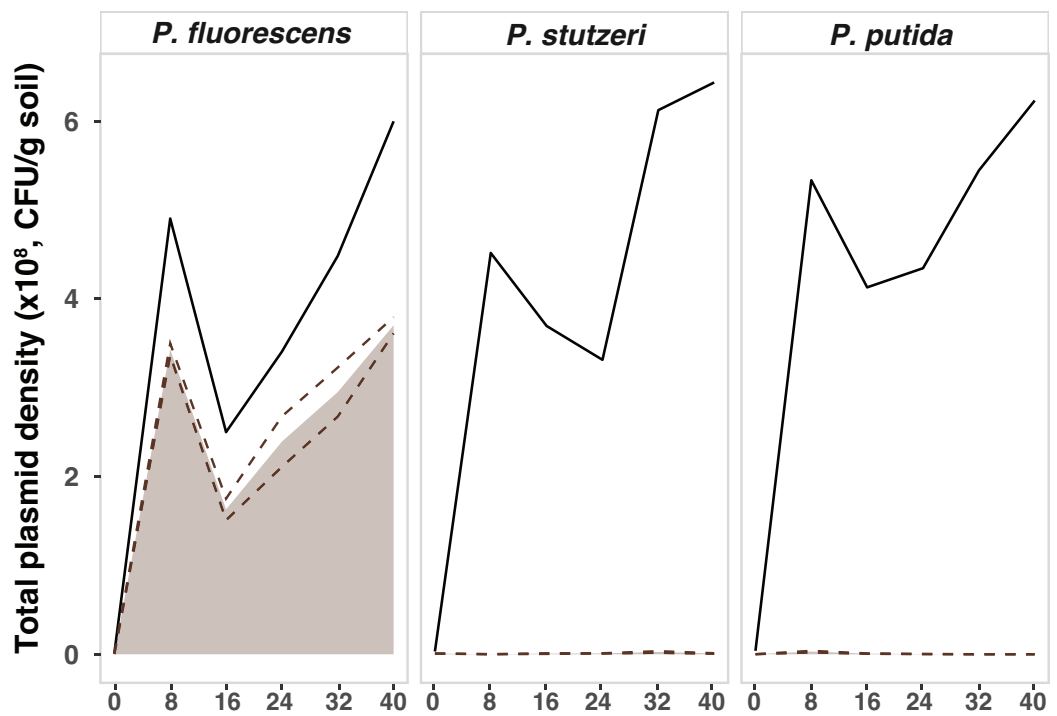

$16 \mu \mathrm{g} / \mathrm{g} \mathrm{Hg}$ (II)

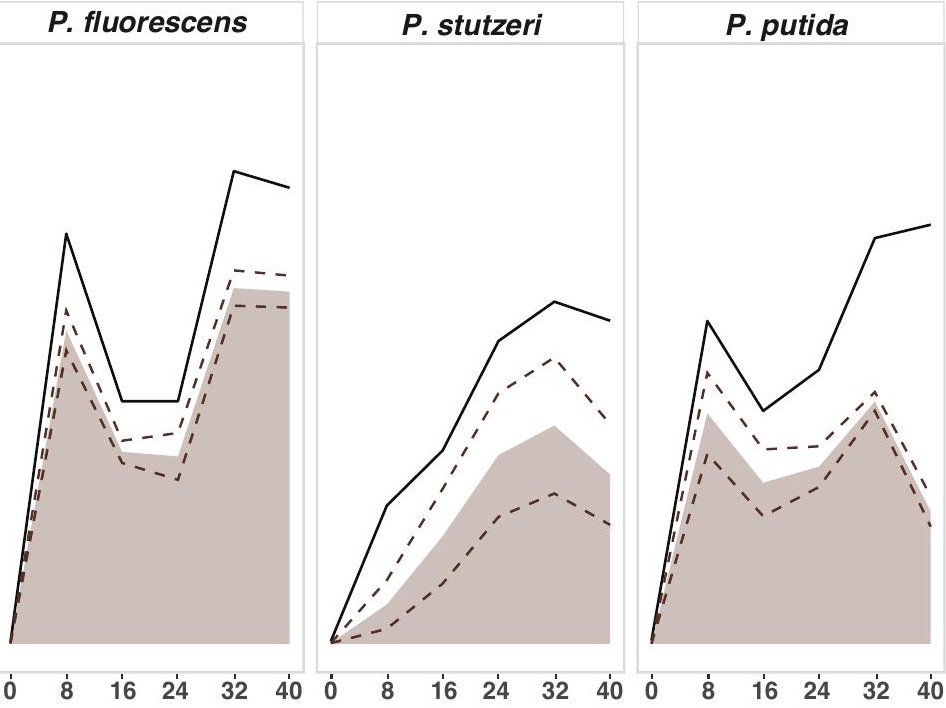

\section{Time (days)}


bioRxiv preprint doi: https://doi.org/10.1101/2020.10.13.337451; this version posted October 13, 2020. The copyright holder for this preprint (which was not certified by peer review) is the author/funder, who has granted bioRxiv a license to display the preprint in perpetuity. It is made available under aCC-BY-NC-ND 4.0 International license.

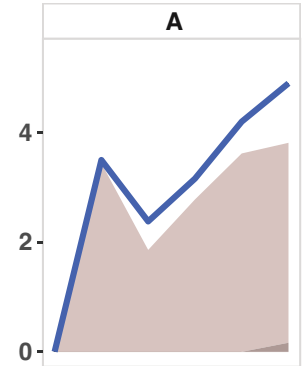

B

C
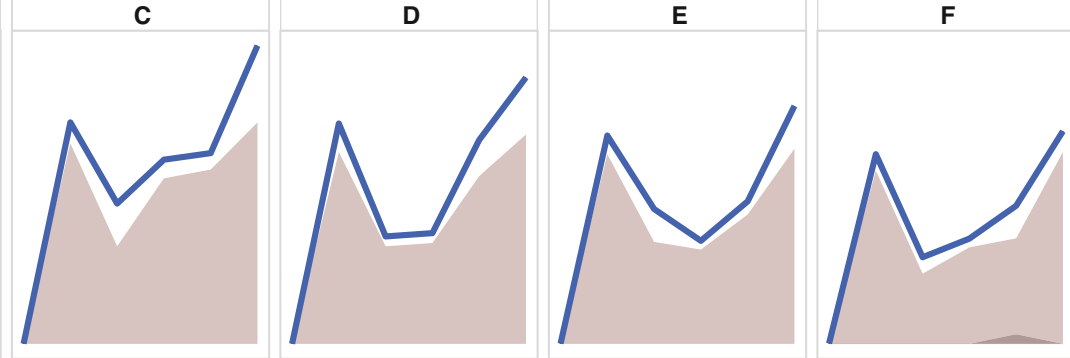

응
종
읕
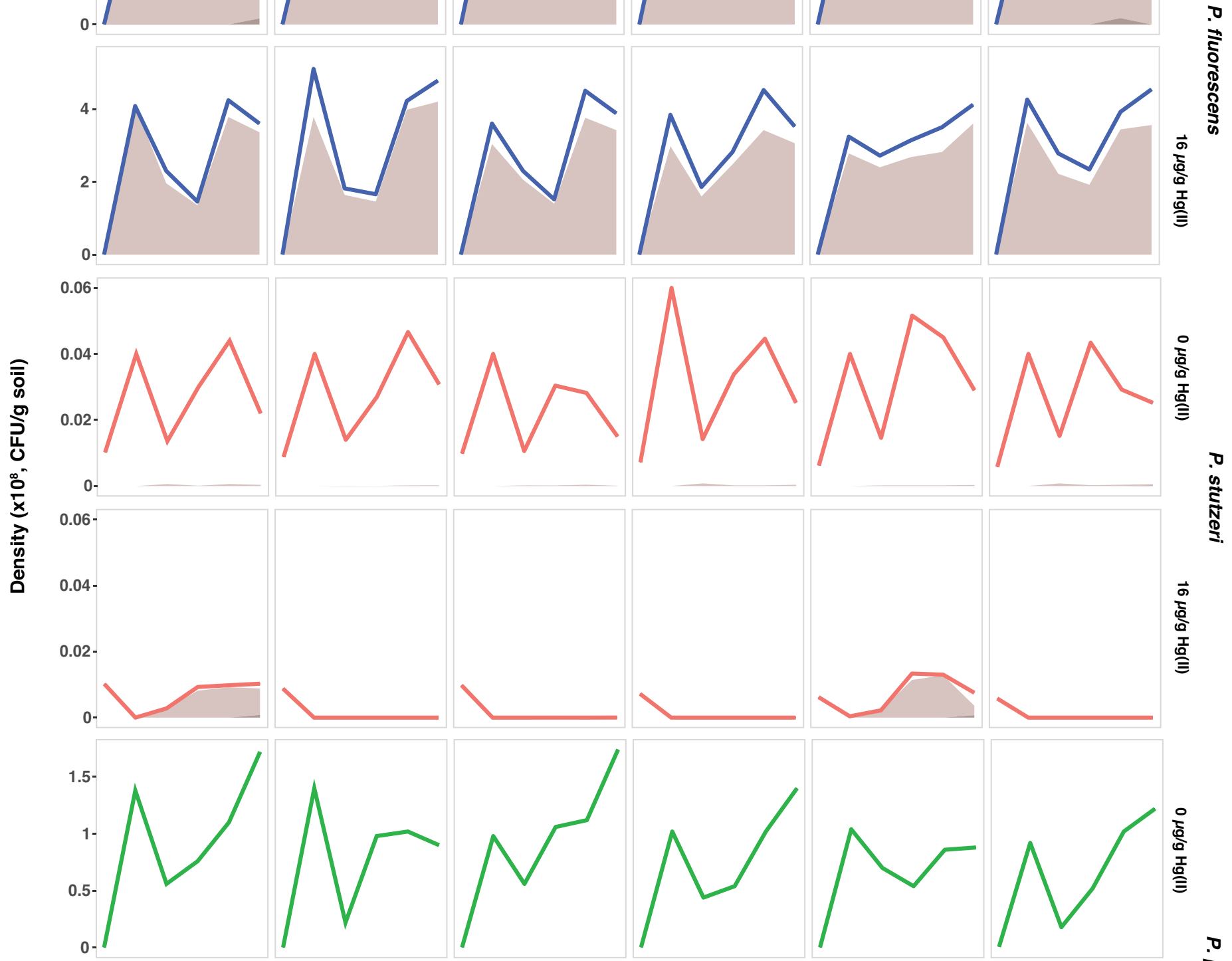

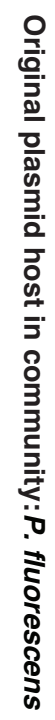
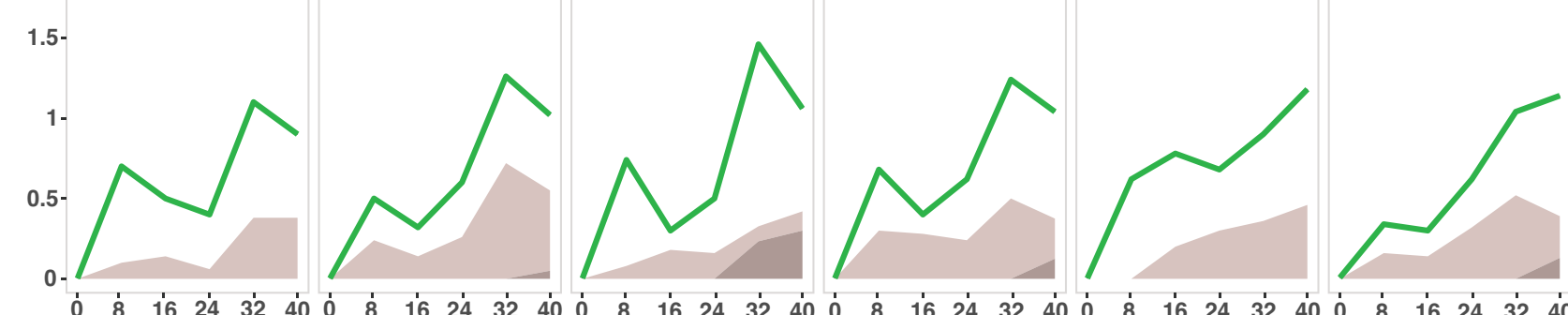

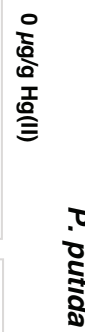

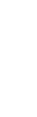

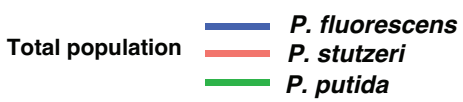

Time (days)

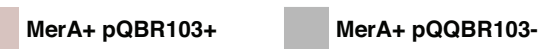


bioRxiv preprint doi: https://doi.org/10.1101/2020.10.13.337451; this version posted October 13, 2020. The copyright holder for this

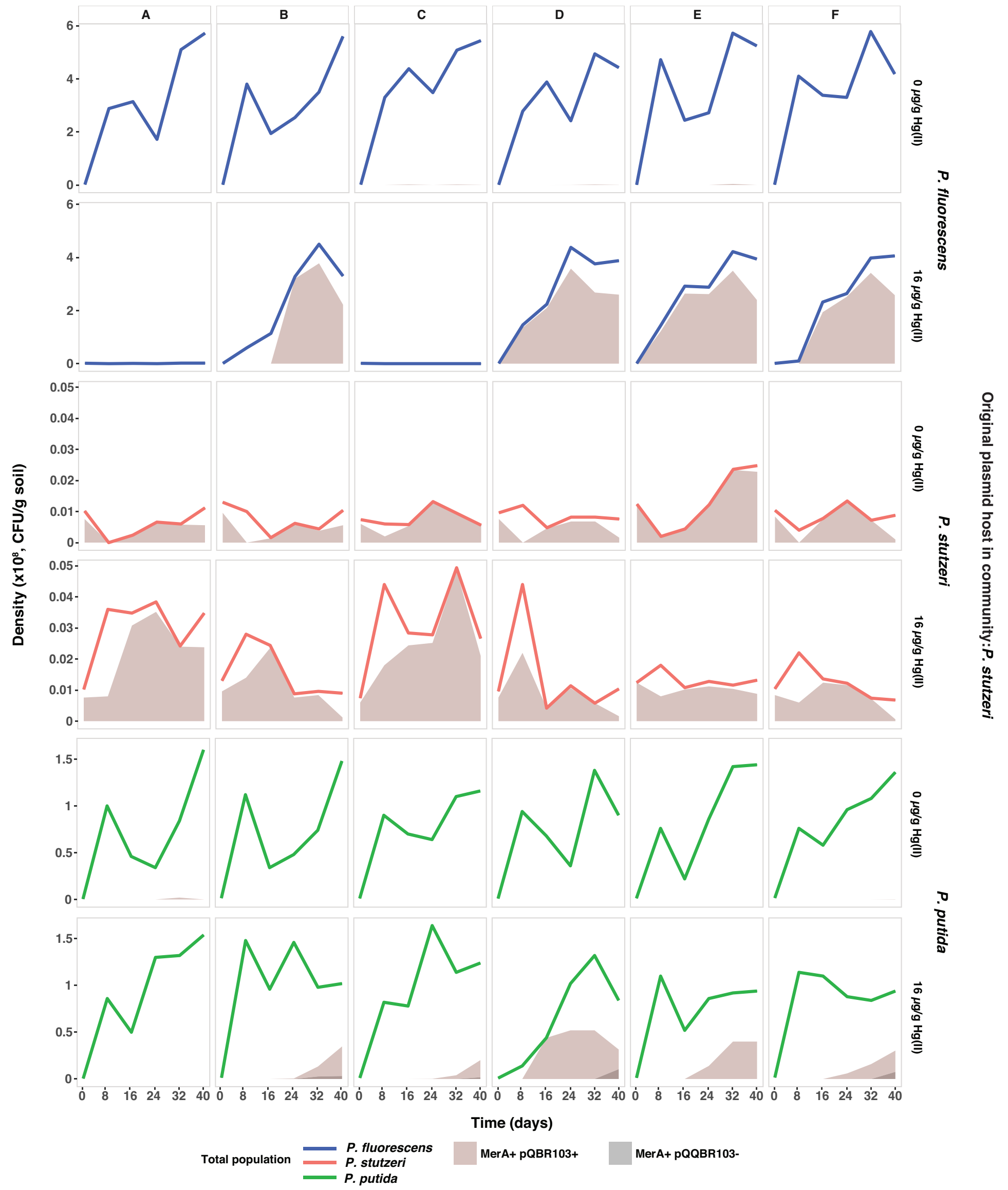


bioRxiv preprint doi: https://doi.org/10.1101/2020.10.13.337451; this version posted October 13, 2020. The copyright holder for this preprint (which was not certified by peer review) is the author/funder, who has granted bioRxiv a license to display the preprint in perpetuity. It is made available under aCC-BY-NC-ND 4.0 International license.

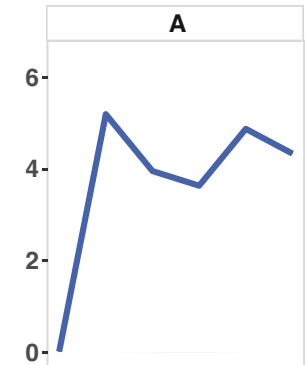

B

C

D

E

$\mathbf{F}$
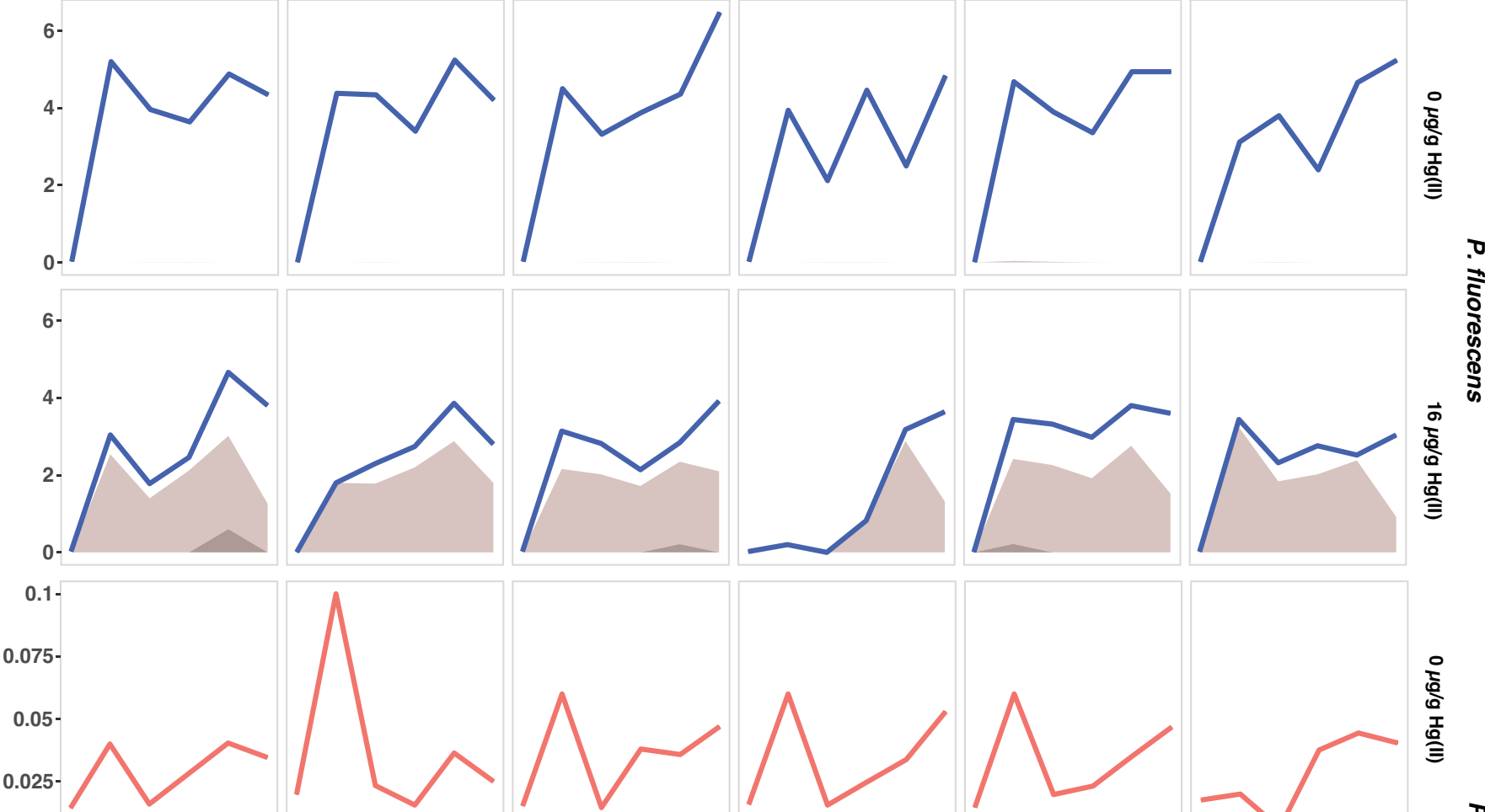

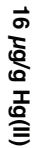

\section{5
0
0
0
0
0
0}
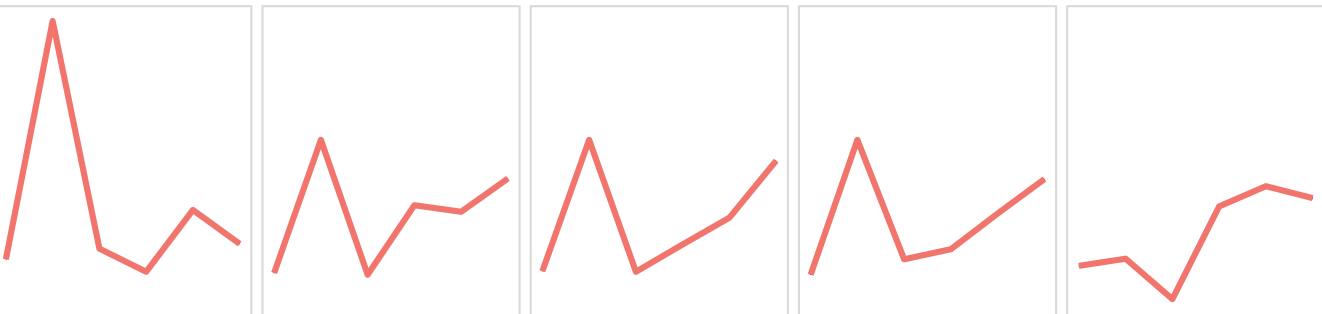

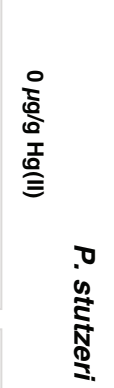

.

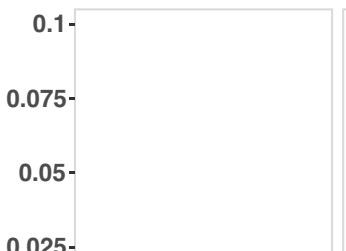

0.025
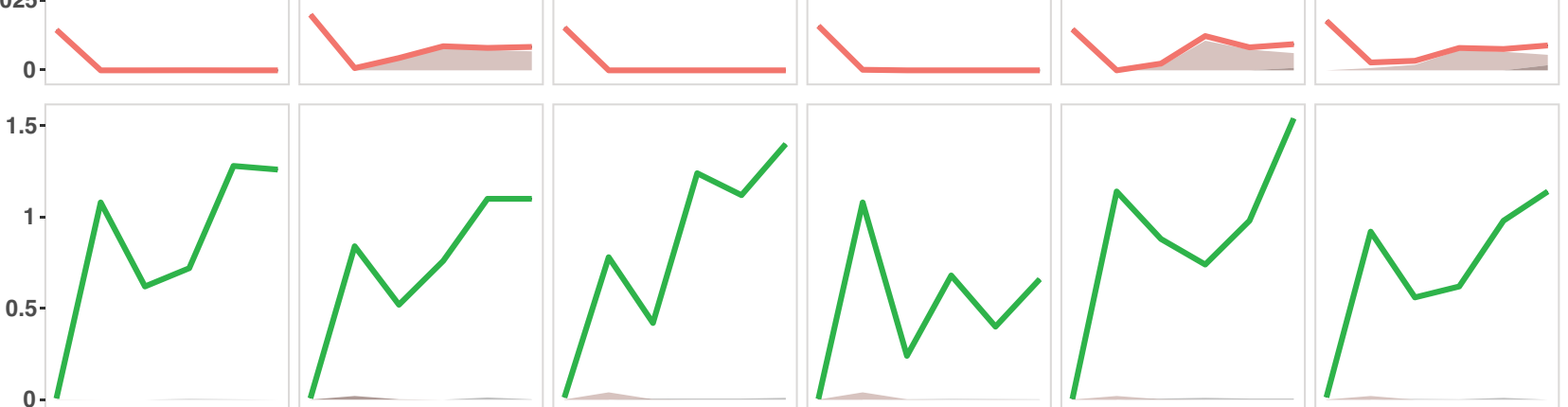

के
응
듵

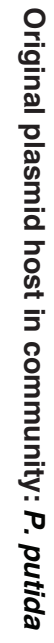
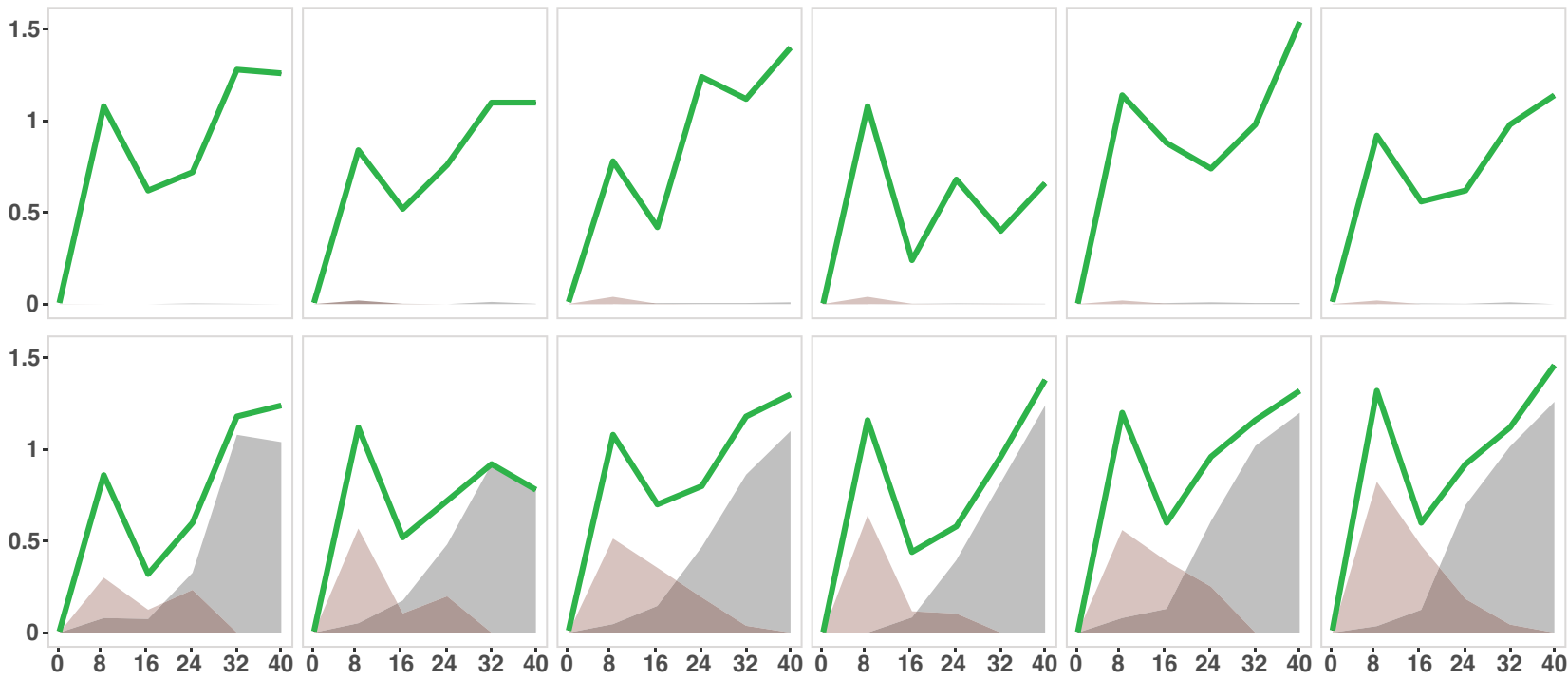

옹
응
종

$\frac{2}{8}$

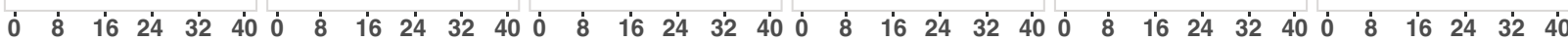

Time (days)

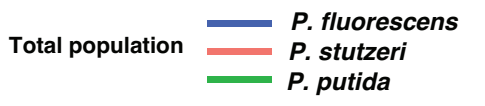

MerA+ pQBR103+

MerA+ pQQBR103- 
bioRxiv preprint doi: https://doi. org/10.1101/2020.10.13.337451; this version posted October 13, 2020. The copyright holder for this preprint (which was not certified by peer review) is the author/funder, who has granted bioRxiv a license to display the preprint in perpetuity. It is made available under aCC-BY-NC-ND 4.0 International license.

0.5 -

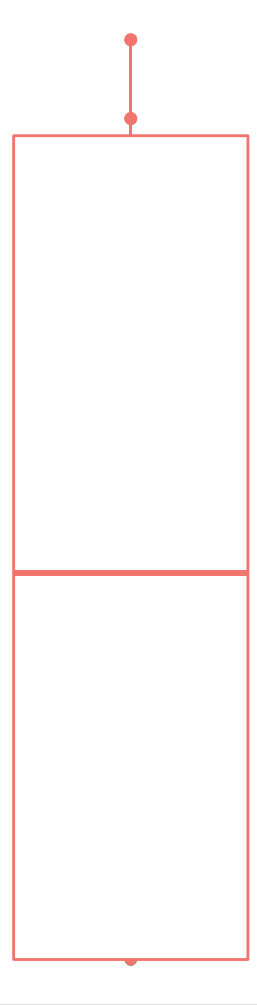

P. fluorescens

P. stutzeri

P. putida

P. fluorescens

P. stutzeri

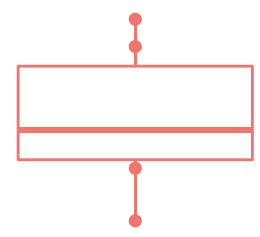

Original plasmid host in community 